\title{
EVALUASI KINERJA GURU BERSERTIFIKASI
}

\author{
Andhika Imam Kartomo \\ Alumni Program Pasca Sarjana Magister Manajemen Pendidikan \\ FKIP-Universitas Kristen Satya Wacana Salatiga \\ andhikaimam66@gmail.com
}

Slameto

Program Pasca Sarjana Magister Manajemen Pendidikan

FKIP-Universitas Kristen Satya Wacana Salatiga

slameto@staff.uksw.edu

\begin{abstract}
The study aimed to evaluate certified teachers performance in Temanggung regency district of Gugus Mangga. This study was evalitative research using qualitative dessciptive approach. Subject of this research are teachers, principals and supervisors. Data were collected through interview, observation and documentation. The results of the study showed that performance of certified teachers in planning aspect of learning and evaluation is in good category. While the performance of certified teachers in presentation and capacity building is in the less than good category. The recommendation given for teachers in preparing lesson plan (RPP) should included aspect of communication and information technologies and also followed by the development of activities. Recommendation for schools is organizing textbooks procurement so that students can have a good process of learning. Recommendation for regional government is to provide assistance of textbooks procurement for schools which has not enough textbook. Besides that the education office recommended to make self-development program for teachers in order to develop and improve the quality of education.
\end{abstract}

Keywords: evaluation, teacher performance, certification

\section{PENDAHULUAN}

Guru adalah pendidik profesional dengan tugas utama mendidik, mengajar, membimbing, mengarahkan, melatih, menilai, dan mengevaluasi peserta didik pada pendidikan anak usia dini jalur pendidikan formal, pendidikan dasar, dan pendidikan menengah (UU No 14 tahun 2005). Seorang guru wajib memiliki kualifikasi akademik, 
kompetensi, sertifikasi pendidik, sehat jasmani dan rohani, serta memiliki kemampuan untuk mewujudkan tujuan pendidikan nasional. Saat ini pemerintah membuat program pengembangan kompetensi guru dengan melakukan program sertifikasi. Sertifikasi guru merupakan salah satu upaya untuk mewujudkan tujuan pendidikan nasional.

Undang-Undang No.14 Tahun 2005 Tentang Guru dan Dosen memberi fasilitas "sertifikasi" bagi para guru dan dosen untuk meningkatkan kesejahteraannya yang diikuti dengan harapan untuk meningkatkan kinerja dan kualitas pembelajaran menuju peningkatan kualitas pendidikan di Indonesia (Sahabuddin, 2014: 01). Namun pelaksanaan di lapangan tidak sesuai harapan. Masih banyak dijumpai guru sertifikasi yang kualitasnya diragukan, karena mereka tidak menguasai teknologi dalam pembelajaran, bahkan masih banyak yang tidak bisa mengoperasikan komputer (Sunantri, 2013: 01).

Kinerja guru dapat dilihat dan diukur berdasarkan spesifikasi/kriteria kompetensi yang harus dimiliki oleh setiap guru. Menurut Undang-Undang Nomor 14 tahun 2005 tentang Guru dan Dosen pasal 1, Ayat 10, kompetensi adalah seperangkat pengetahuan, keterampilan, dan perilaku yang harus dimiliki, dihayati dan dikuasai oleh guru atau dosen dalam melaksanakan tugas keprofesionalan. Sedang pasal 10 ayat 1 menyatakan bahwa kompetensi pendidik sebagai agen pembelajaran pada jenjang pendidikan dasar dan menengah serta pendidikan anak usia dini meliputi kompetensi pedagogik, kompetensi kepribadian, kompetensi profesional, dan kompetensi sosial.

Kinerja atau prestasi kerja adalah hasil kerja secara kualitas dan kuantitas yang dicapai oleh seseorang dalam mengimplementasikan tugasnya sesuai dengan tanggung jawab yang diberikan kepadanya (Mangkunegara, 2007: 09). Bila dikaitkan dengan guru maka kinerja guru tidak lain adalah kemampuan guru untuk menampilkan atau mengerjakan tugas guru. Kinerja guru dapat tercermin dalam perilaku guru dalam proses pembelajaran.

Menurut Yusrizal, Soewarno S, Zarlaida Fitri (2011: 01) guru Fisika, Biologi, dan Kimia SMA yang sudah lulus sertifikasi dan sudah menerima tunjangan belum seluruhnya berkinerja tinggi. Padahal semestinya setiap guru pemegang sertifikasi wajib menunjukkan kinerja terbaik dalam menjalankan tugas dan pengabdian untuk mencerdaskan para peserta didik. Untuk menunjang pelaksanaan pembelajaran, guru senantiasa harus terus berusaha untuk menambah pengetahuannya sesuai dengan perkembangan jaman. Pengembangan diri guru wajib dilakukan agar mereka terus bekerja dengan baik. Guru perlu merencanakan kegiatan pengembangan diri, misalnya melalui pelatihan, seminar, workshop, kursus, diskusi kelompok kecil, studi banding, tutorial, pembinaan dan lain sebagainya. Pengembangan diri guru itu dilakukan sebagai upaya peningkatan kualitas kinerja.

Kinerja dan kualitas mengajar para guru yang sudah bersertifikasi perlu dievaluasi secara periodik (Kompas, 2010: 01). Melalui program evaluasi akan diketahui sejauh mana kinerja masing-masing guru pemegang sertifikasi melaksanakan tugas dan pengabdian dalam upaya mencerdaskan para siswa. Peraturan Menteri Pendikan Nasional No. 41 tahun 2007 tentang Standar Proses Pendidikan Dasar dan Menengah, merupakan acuan utama bagi guru dalam merencanakan proses pembelajaran, melaksanakan pembelajaran, melakukan penilaian hasil belajar serta melaksanakan tindak lanjut.

Secara administratif kependidikan, perangkat pembelajaran guru di Gugus Mangga belum sepenuhnya lengkap. Tidak semua Guru di Gugus Mangga membuat perangkat 
pembelajaran pada awal semester. Guru kurang siap dalam merencanakan, melaksanakan dan mengevaluasi pembelajaran sehingga hasil yang diperoleh oleh siswa kurang maksimal. Buku teks pelajaran bagi peserta didik juga belum terpenuhi. Berkaitan dengan aspek pengembangan diri, masih terdapat banyak guru yang belum melaksanakan pengembangan diri sesuai dengan keprofesionalannya sebagai seorang guru. Dengan demikian untuk mengetahui kinerja guru di Gugus Mangga perlu dilaksanakanya evaluasi terhadap komponen kinerja guru.

Evaluasi merupakan pemberian nilai terhadap hasil tujuan atau sasaran kebijakan. Sementara itu Arikunto, Suharismi dan Cepi Safrudin. (2008: 2) berpendapat bahwa evaluasi merupakan kegiatan untuk mengumpulkan informasi tentang bekerjanya sesuatu, yang selanjutnya informasi tersebut digunakan untuk menentukan alternatif yang tepat dalam mengambil keputusan. Widoyoko (2014: 04) menambahkan bahwa evaluasi adalah penyediaan informasi yang dapat dijadikan sebagai bahan pertimbangan dalam mengambil keputusan. Menurut Danim (2000: 14), penilaian adalah proses pengukuran dan perbadingan dari hasil-hasil pekerjaan yang nyatanya dengan hasil-hasil yang seharusnya. Sejalan dengan hal tersebut Wirawan (2009: 03), menambahkan bahwa evaluasi adalah proses mengumpulkan informasi mengenai objek evaluasi dan menilai objek evaluasi dan membandingkannya dengan standar evaluasi. Hasilnya berupa informasi kemudian dapat digunakan untuk mengambil keputusan mengenai objek evaluasi. Berdasarkan uraian diatas dapat diartikan bahwa evaluasi merupakan suatu kegiatan yang dilakukan untuk mengukur serta membandingkan hasil-hasil pelaksanaan kegiatan dengan standar yang telah dicapai sehingga diperoleh informasi nilai atau manfaat suatu objek evaluasi. Informasi yang diperoleh dapat digunakan dalam alternatif pengambilan suatu keputusan.

Istilah kinerja berasal dari kata job performance atau actual performance (prestasi kerja atau prestasi sesungguhnya yang dicapai seseorang) yaitu hasil kerja secara kualitas dan kuantitas yang dicapai oleh seorang pegawai dalam melaksanakan tugasnya sesuai dengan tanggung jawab yang diberikannya (Mangkunegara, 2005: 67). Sejalan dengan hal tersebut Hasibuan (2005: 94) menyatakan bahwa kinerja (prestasi kerja) adalah suatu hasil kerja yang dicapai seseorang dalam melaksanakan tugas-tugas yang dibebankan kepadanya yang didasarkan atas kecakapan, pengalaman dan kesungguhan serta waktu. Menurut Moeheriono (2012: 65) kinerja adalah catatan tentang hasil-hasil yang diperoleh dari fungsi-fungsi pekerjaan atau kegiatan tertentu selama kurun waktu tertentu. Sejalan dengan hal tersebut Wirawan (2009: 05), menyatakan bahwa kinerja adalah keluaran yang dihasilkan oleh fungsifungsi atau indikator-indikator suatu pekerjaan atau suatu profesi dalam waktu tertentu. Menurut Rivai (2005: 14) kinerja adalah tingkat keberhasilan seseorang selama periode tertentu dalam melaksanakan tugas yang dibandingkan dengan berbagai kemungkinan, seperti standar hasil kerja, target atau sasaran atau kriteria yang telah ditentukan terlebih dahulu dan telah disepakati bersama. Berdasarkan pendapat diatas bahwa kinerja merupakan hasil kerja yang dicapai seseorang dalam melaksanakan tugas kerjanya sesuai dengan tangung jawabnya yang dibandingkan dengan indikator-indikator, standar hasil kerja, atau kriteria yang telah ditentukan terlebih dahulu. Untuk mengetahui hasil kerja yang telah dicapai seseorang dalam organisasi perlu dilakukan penilaian kinerja.

Evaluasi kinerja adalah suatu metode dan proses penilaian pelaksanaan tugas (performance) seseorang atau sekelompok orang atau unit-unit kerja dalam satu perusahaan 
atau organisasi sesuai dengan standar kinerja atau tujuan yang ditetapkan lebih dahulu (Simanjuntak, 2005: 103). Sejalan dengan hal tersebut Uno (2012: 12) berpendapat bahwa evaluasi kinerja adalah proses yang mengukur kinerja seseorang dimana dalam proses pengukurannya akan selalu dibandingkan dengan standar, target/sasaran, atau kriteria yang telah ditetapkan terlebih dahulu dan sudah disepakati bersama. Menurut Wirawan (2012: 11) bahwa evaluasi kinerja merupakan proses melakukan penilaian mengenai kinerja ternilai yang didokumentasikan secara formal untuk menilai kinerja ternilai dengan membandingkan standar kinerjanya secara periodik untuk membantu pengambilan keputusan manajemen sumber daya manusia. Sementara itu Nawawi (2006: 73) mengemukakan evaluasi kinerja diartikan juga sebagai kegiatan mengukur/menilai pelaksanaan pekerjaan untuk menetapkan sukses atau gagalnya seorang pekerjaan dalam melaksanakan tugas dan tanggung jawabnya di bidang kerjanya masing masing. Berdasarkan pengertian tersebut maka evaluasi kinerja merupakan suatu proses penilaian kerja seseorang dalam melakukan pekerjaanya sesuai tugas dan tanggung jawabnya dengan membandingkan standar kinerja sesuai kriteria yang telah ditetapkan terlebih dahulu. Hasil dari evaluasi dapat digunakan sebagai masukan untuk melakukan kegiatan yang lebih baik pada masa akan datang.

Kinerja guru merupakan perilaku guru dalam melaksanakan tugasnya sebagai seorang pendidik. Menurut Permendiknas No. 41 Tahun 2007 tentang Standar Proses untuk Satuan Pendidikan Dasar dan Menengah, dijelaskan bahwa yang dimaksud dengan kinerja guru adalah prestasi mengajar yang dihasilkan dari aktivitas yang dilakukan guru dalam melaksanakan tugas pokok dan fungsinya secara realisasi konkrit merupakan konsekuensi logis sebagai tenaga profesional di bidang pendidikan. Mulyasa (2004) berpendapat bahwa guru yang memiliki kinerja tinggi akan bernafsu dan berusaha meningkatkan kompetensinya baik dalam kaitannya perencanaan, pelaksanaan maupun penilaian pembelajaran sehingga diperoleh hasil kerja yang optimal. Sejalan dengan itu, Rusman (2009: 319) berpendapat bahwa wujud perilaku dalam kinerja guru dalam proses pembelajaran yaitu bagaimana seorang guru merencanakan pembelajaran, melaksanakan kegiatan pembelajaran, menilai hasil pembelajaran serta melaksanakan tindak lanjut pembelajaran.

Kinerja guru berkaitan dengan tugas perencanaan, pengelolaan pembelajaran dan penilaian hasil belajar siswa (Sanjaya, 2005; 13). Sebagai seorang perencana, maka guru harus mampu mendesain pembelajaran yang sesuai dengan kondisi di lapangan, sebagai pengelola maka guru harus mampu menciptakan iklim pembelajaran yang kondusif sehingga siswa dapat belajar dengan baik, dan sebagai evaluator maka guru harus mampu melaksanakan penilaian proses dan hasil belajar siswa. Menurut Yamin (2010: 87) kinerja guru adalah perilaku atau respon yang memberi hasil yang mengacu kepada apa yang mereka kerjakan ketika dia menghadapi suatu tugas. Beberapa aktifitas tersebut antara lain; 1) kegiatan sebelum mengajar, 2) kegiatan selama mengajar, 3) kegiatan selama segmen mengajar, 4) kegiatan tentang keterlibatan tenaga pengajar dalam masyarakat, pendidik atau lingkungan secara lebih luas. Menurut UU no 14 Tahun 2005 bab IV 20a tentang Guru dan Dosen dalam melaksanakan tugas keprofesionalnya guru berkewajiban merencanakan pembelajaran, melaksanakan proses pembelajaran yang bermutu, serta menilai dan mengevaluasi hasil pembelajaran. Perihal tenaga pengajar dengan kinerjanya adalah menyangkut seluruh aktifitas yang ditunjukkan oleh tenaga pengajar dalam tanggung 
jawabnya sebagai orang yang mengemban suatu amanat dan tangung jawab untuk mendidik, mengajar, membimbing, mengarahkan dan memandu peserta didik dalam rangka mengiring perkembangan peserta didik kearah kedewasaan mental-spiritual maupun fisik-biologis (Yamin, 2010: 87).

Berdasarkan Peraturan Menteri Pendidikan Nasional (Permendiknas) Nomor 41 tahun 2007 tentang standar proses untuk satuan pendidikan dasar dan menengah, bahwa standar proses berisi kriteria minimal proses pembelajaran pada satuan pendidikan dasar dan menengah diseluruh wilayah hukum Negara Kesatuan Republik Indonesia. Standar proses meliputi perencanaan proses pembelajaran, pelaksanaan proses pembelajaran, penilaian hasil pembelajaran, dan pengawasan hasil pembelajaran untuk terlaksananya proses pembelajaran yang efektif dan efisien. Sebagai guru profesional selayaknya guru selalu meningkatkan kinerjanya. Pengembangan diri merupakan salah satu kegiatan yang dilakukan guru untuk meningkatkan kompetensi dan keprofesiannya untuk menunjang kinerjanya. Menurut Kemendiknas, (2010: 15), kegiatan tersebut dilakukan melalui pendidikan dan pelatihan (diklat) fungsional dan/atau melalui kegiatan kolektif guru.

Dari uraian pendapat diatas bahwa kinerja guru merupakan perilaku guru dalam proses pembelajaran dari proses merencanakan pembelajaran, melaksanakan kegiatan pembelajaran, menilai hasil pembelajaran, dan pengembangan diri. Untuk mengetahui kinerja guru maka diperlukan standar kinerja untuk dijadikan acuan dalam mengadakan penilaian, yaitu membandingkan apa yang dicapai dengan apa yang diharapkan.

Sertifikasi adalah proses pemberian sertifikat pendidik untuk guru dan dosen. Sertifikat pendidik adalah bukti formal sebagai pengakuan yang diberikan kepada guru dan dosen sebagai tenaga profesional (UU No 14 tahun 2005). Menurut Muslich (2007: 02) Sertifikasi adalah proses pemberian sertifikat pendidik kepada guru yang telah memenuhi persyaratan tertentu yaitu memiliki kualifikasi akademik, kompetensi sehat jasmani dan rohani, serta memiliki kemampuan untuk mewujudkan tujuan pendidikan nasional, yang diikuti dengan peningkatan kesejahteraan yang layak. Sertifikasi guru merupakan suatu proses pemberian pengakuan bahwa seseorang telah memiliki kompetensi untuk melaksanakan pelayanan pendidikan pada satuan pendidikan tertentu, setelah lulus uji kompetensi yang diselenggarakan oleh lembaga sertifikasi. Dengan kata lain sertifikasi guru adalah proses uji kompetensi yang dirancang untuk mengungkapkan penguasaan kompetensi seseorang sebagai landasan pemberian sertifikat pendidik (Mulyasa, 2007: 33). Sertifikasi guru sebagai upaya peningkatan mutu guru dibarengi dengan peningkatan kesejahteraan guru sehingga diharapkan dapat meningkatkan mutu pembelajaran dan mutu pendidikan di Indonesia secara berkelanjutan. Bentuk peningkatan kesejahteraan guru berupa tunjangan profesi sebesar satu kali gaji pokok bagi guru yang memiliki sertifikasi pendidik (Kunandar, 2008: 79).

Dari uraian diatas, sertifikasi guru merupakan suatu proses pemberian pengakuan kepada guru telah memiliki kompetensi untuk melaksanakan pelayanan pendidikan setelah lulus uji kompetensi yang diselenggarakan oleh lembaga sertifikasi. Sertifikasi guru merupakan salah satu usaha meningkatkan kompetensi profesional.

Suatu organisasi mempunyai model sistem evaluasi yang berbeda mengenai dimensi kerja, indikator kinerja, standar kinerja dan instrument kinerja yang berbeda satu sama lain. Dalam merancang dan mendesain evaluasi, evaluator harus menentukan model evaluasi apa 
yang dipergunakan. Model-model evaluasi menurut Wirawan (2009: 82-95), yang digunakan berbagai organisasi yaitu Model Esai, Model Critical Incident, Model Method, Model Checklist, Model Graphic Ranting Scale, Model Forced Distribution, Model Forced Choice Scale, Model Behaviorally Anchor Rating Scale, Model Behavior Observation Scale, Model Behavior Expectation Scale, Management By Objective, 360 Degre Performance Appraisal Model Dan Model Paired Comparation.

Berdasarkan model-model evaluasi di atas, model yang digunakan dalam penelitian ini adalah Model Checklist. Menurut Wirawan (2009: 88), evaluasi kinerja model Checklist berisi daftar indikator-indikator hasil kerja, perilaku kerja, atau sifat pribadi yang diperlukan dalam melaksanakan pekerjaan. Untuk evaluasi berdasarkan model ini menggunakan sejumlah pertanyaan dengan menggunakan formulir isian yang menjelaskan beraneka macam tingkat perilaku bagi suatu pekerjaan tertentu (Moeheriono, 2012: 141). Model ini dipergunakan untuk mengamati perilaku dalam bekerja, dengan memberikan tanda/simbol tertentu bilamana perilaku yang dimaksud dilaksanakan, pada kolom yang sesuai dengan kualitasnya. Dalam model evaluasi kinerja Checklist penilai mengobservasi kinerja ternilai kemudian memilih indikator yang melukiskan kinerja atau karakteristik ternilai dan memberi tanda cek (Wirawan, 2009: 88). Menurut Nawawi (2011: 272), Model ini mudah menggunakannya dan berkaitan langsung dengan analisis pekerjaan karena didalamnya telah terdapat secara rinci tugas yang harus dilaksanakan. Keunggunlan model ini biaya murah, pengurusanya mudah, penilai hanya membutuhkan pelatihan yang sederhana dan distandarisasi (Moeheriono, 2012: 142).

Rumusan masalah dalam penelitian ini adalah: bagaimana kinerja guru sertifikasi Gugus Mangga berdasarkan standar proses pendidikan. Tujuan dari penelitian ini adalah untuk mengevaluasi kinerja guru sertifikasi Gugus Mangga berdasarkan standar proses pendidikan

\section{METODE PENELITIAN}

Jenis penelitian ini adalah penelitian evaluasi dengan pendekatan kualitatif. Penelitian evaluasi ditujukan untuk mengevaluasi Kinerja Guru Sertifikasi Gugus Mangga Kecamatan Candiroto. Pendekatan kualitatif diharapkan dapat menghasilkan informasi yang mendalam dan rinci, sehingga memberikan gambaran mengenai realita kinerja Guru Sertifikasi Gugus Mangga Kecamatan Candiroto.

Lokasi pada peneltian ini yaitu di SD Negeri Muntung, SD Negeri Krawitan, SD Negeri 1 Batursari, SD Negeri Mento dan SD Negeri Mentisari. Subjek dalam penelitian ini adalah nara sumber, partisipan atau informan. Sumber data berasal dari 5 SD yaitu Pengawas, tiga Kepala Sekolah dan Guru.

Data penelitian diperoleh melalui teknik wawancara, yang terdiri dari wawancara. Di mana peneliti menyiapkan instrumen berupa pertanyaan-pertanyaan tertulis yang diadopsi dari Peraturan Menteri Pendidikan Nasional (Permendiknas) Nomor 41 tahun 2007 tentang standar proses untuk satuan pendidikan dasar dan menengah. Untuk melengkapi hasil wawancara tersebut dilakukan studi dokumentasi dan observasi.

Uji keabsahan yang digunakan adalah triangulasi sumber dan triangulasi teknik. Triangulasi sumber digunakan untuk mendukung hasil wawancara. Hasil wawancara guru 
dicocokan (cross check) dengan hasil wawancara pengawas, dan kepala sekolah dengan instrumen pertanyaan yang sama. Triangulasi teknik digunakan untuk mencocokan data yang diperoleh dari wawancara, observasi dan dokumentasi.

Teknik analisis data dalam penelitian kualitatif dilakukan sebelum penelitian, selama penelitian dan sesudah penelitian. Analisis data selama dilapangan dilakukan secara terus menerus hingga datanya jenuh dan memperoleh hasil yang di inginkan. Aktivitas tersebut meliputi reduksi data, display data dan kesimpulan atau verifikasi yang kemudian akan di bawa untuk analisis setelah penelitian.

\section{HASIL PENELITIAN DAN PEMBAHASAN}

Tujuan penelitian ini adalah mengevaluasi kinerja Guru Sertifikasi Gugus Mangga Kecamatan Candiroto berdasarkan standar proses pendidikan. Hasil dari evaluasi diharapkan dapat memberikan manfaat sebagai bahan rekomendasi dalam memperbaiki kinerja guru sertifikasi sehingga kinerja guru akan semakin lebih baik. Hal tersebut sejalan dengan pengertian evaluasi (Widoyoko, 2014: 04) yaitu penyediaan informasi yang dapat dijadikan sebagai bahan pertimbangan dalam mengambil keputusan.

Penelitian dimulai dari proses mengumpulkan data, menilai, dan menyimpulkannya. Berbagai latar belakang dan kemungkinan yang diperoleh dari hasil wawancara, observasi dan dokumentasi yang akan menentukan bahwa kinerja guru sertifikasi masuk dalam kategori baik, kurang baik, atau tidak baik.

Evaluasi kinerja adalah proses yang mengukur kinerja seseorang dimana dalam proses pengukurannya akan selalu dibandingkan dengan standar, target/sasaran, atau kriteria yang telah ditetapkan terlebih dahulu dan sudah disepakati bersama (Uno, 2012: 12). Pada penelitian ini standar kinerja guru berdasarkan standar proses pendidikan.

Pada penelitian sebelumnya oleh Suratno, M. Rusdi, Hary Soedarta H. (2010: 37) ditemukan bahwa guru sekolah dasar profesional secara umum berkinerja dalam kategori baik. Namun dalam beberapa hal belum mencapai kualifikasi kerja yang diharapkan. Oleh karena itu, evaluasi kinerja guru dilakukan guna mengidentifikasi indikator-indikator kinerja guru. Terhadap kelemahan yang ditemukan maka dapat diajukan rekomendasi yang relevan.

Komponen pertama dalam kinerja guru adalah perencanaan proses pembelajaran. Menurut Peraturan Pemerintah (PP) No 19 tahun 2005 pasal 20 berbunyi bahwa perencanaan proses pembelajaran meliputi silabus dan rencana pelaksanaan pembelajaran yang memuat sekurang-kurangnya tujuan pemebelajaran, materi pembelajaran, metode pembelajaran, sumber belajar dan penilaian hasil belajar. Indikator perencanaan proses pembelajaran yang pertama adalah menyusun silabus.

Silabus merupakan seperangkat rencana serta pengaturan pelaksanaan pembelajaran dan penilaian yang disusun secara sistematis yang memuat komponen-komponen yang saling berkaitan untuk mencapai penguasaan kompetensi dasar (Yulaelawati, 2004: 123). Berdasarkan hasil analisis perencanaan proses pembelajaran sudah sesuai dengan ketentuan yang ada. Guru telah menyusun silabus pada masuk awal semester dan ada yang menyusun sebelum semester dimulai. Silabus yang telah disusun telah sesuai dengan ketentuan standar proses yang meliputi identitas mata pelajaran, standar kompetensi, kompetensi dasar, indikator pencapaian kompetensi, materi pembelajaran, kegiatan pembelajaran, penilaian, 
alokasi waktu, dan sumber belajar. Kebanyakan guru menyusun silabus secara mandiri dan ada dua sekolah yang menyusun dengan tim sekolah.

Indikator perencanaan proses pembelajaran yang kedua yaitu menyusun rencana pelaksanaan pembelajaran. Rencana pelaksanaan pembelajaran adalah rencana yang menggambarkan prosedur dan manajemen pembelajaran untuk mencapai satu atau lebih kompetensi dasar yang ditetapkan dalam standar isi dan dijabarkan dalam silabus (Mulyasa, 2003: 212). Guru menyusun rencana pelaksanaan pembelajaran pada awal semester secara mandiri. Rencana pelaksanaan pembelajaran yang disusun telah sesuai dengan standar proses yang meliputi identitas mata pelajaran, standar kompetensi, kompetensi dasar, indikator pencapaian kompetensi, tujuan pembelajaran, materi pembelajaran, kegiatan pembelajaran, penilaian, alokasi waktu, dan sumber belajar yang sudah adanya keterkaitan.

Penyusunan rencana pelaksanaan pembelajaran telah menggunakan berbagai model atau metode yang disesuaikan dengan karakteristik siswa agar siswa aktif dalam mengikuti pembelajaran. Rencana pelaksanaan pembelajaran yang disusun sudah terdapat sistem penilaian untuk mengukur ketercapaian kompetensi peserta didik. Selain itu juga telah membuat program remidi dan pengayaan sebagai tindak lanjut dari hasil penilaian. Pada rencana pelaksanaan pembelajaran yang disusun masih sedikit guru yang menggunakan teknologi informasi dan komunikasi.

Komponen yang kedua evaluasi kinerja guru adalah pelaksanaan proses pembelajaran. Berdasarkan hasil analisis diatas bahwa persyaratan pelaksanaan proses pembelajaran dan pelaksanaan proses pembelajaran secara umum baik, namun ada beberapa aspek yang belum terpenuhi. Pada persyaratan pembelajaran tidak ada rombongan belajar yang melebihi 28 peserta didik. Di salah satu sekolah yang muridnya mencapai 42 dalam satu kelasnya telah dibagi 2 menjadi kelas pararel. Beban mengajar guru keseluruhan telah memenuhi 24 jam perminggu. Namun dalam buku teks pelajaran terdapat sekolah yang belum memenuhi rasio satu buku untuk satu peserta didik. Masih ada yang satu buku pelajaran digunakan dua sampai tiga siswa. Hal tersebut terjadi di dua sekolah yang belum memenuhi rasio satu anak satu buku.

Usaha dalam mengelolaan kelas dilakukan oleh guru agar suasana kelas dapat kondusif untuk melaksanakan kegiatan belajar mengajar. Guru melaksanakan kegiatan pembelajaran dengan baik mulai dari kegiatan pendahuluan berupa doa, memberikan apersepsi dan motivasi, menyampaikan tujuan pembelajaran dan cakupan materi pelajaran.

Guru melaksanakan kegiatan inti untuk mencapai kompetensi dasar yang dilakukan secara interaktif, menyenangkan, dan memotivasi peserta didik untuk berpartisipasi aktif dalam pembelajaran. Kegiatan inti dimulai dari kegiatan eksplorasi yang mengajak siswa untuk menggali informasi tentang materi yang dipelajari dan memberi kesempatan kepada peserta didik untuk mencari berbagai informasi, pemecahan masalah, dan inovasi. Selanjutnya kegiatan elaborasi mendorong siswa agar aktif dalam berbagai kegiatan belajar dengan memungkinkan peserta didik mengekspresikan dan mengaktualisasikan diri melalui berbagai kegiatan dan karya yang bermakna. Kegiatan konfirmasi untuk memberikan klarifikasi, refleksi dan umpan balik yang memberi kesempatan bagi peserta didik untuk dinilai, diberi penguatan dan diperbaiki dari kegiatan pembelajaran sesuai dengan yang dipelajari peserta didik. Pada kegiatan penutup guru membimbing siswa untuk merangkum 
tentang pelajaran yang telah dipelajari. Melakukan penilaian dan/atau refleksi terhadap kegiatan yang sudah dilaksanakan secara konsisten dan terprogram. Memberikan umpan balik terhadap proses dan hasil pembelajaran. Melaksanakan kegiatan tindak lanjut dalam bentuk pembelajaran remidi, program pengayaan, dan/atau memberikan tugas. Terakhir guru menyampaikan rencana pembelajaran berikutnya.

Komponen ketiga dari kinerja guru yaitu penilaian. Penilaian dilakukan untuk mengukur ketercapaian kompetensi peserta didik. Hal tersebut sejalan dengan Sudijono (2006: 157) yaitu penilaian dilakukan oleh guru terhadap hasil pembelajaran untuk mengukur tingkat pencapaian kompetensi peserta didik, serta digunakan sebagai bahan penyusunan laporan kemajuan hasil belajar, dan memperbaiki proses pembelajaran. Penilaian dilakukan guru pada akhir pembelajaran. Guru telah memakai berbagai teknik penilaian. Dari hasil dokumentasi terdapat berbagai macam hasil pekerjaan siswa seperti kliping, laporan kerja kelompok, dari buku skrip, dan portofolio. Penyusunan intrumen disesuaikan dengan indikator dan tujuan pembelajaran. Dalam menggunakan teknik tes biasanya soal sangat bervariatif mulai dari pilihan ganda, memasangkan soal dan jawaban, isian singkat dan uraian. Hasil penilaian siswa telah di dokumentasikan di buku daftar nilai dengan baik.

Komponen yang terakhir adalah evaluasi terhadap pengembangan diri guru. Pengembangan diri yang berupa diklat dilakukan oleh beberapa guru saja. Terdapat 3 sekolah saja yang gurunya melakukan kegiatan diklat. Mereka mengikuti diklat berupa training, pelatihan pembuatan penelitian dan pengembangan keprofesian berkelanjutan. Sebagian guru belum melakukan kegitan pengembangan diri berupa diklat. Berkaitan dengan kegiatan kolektif guru, belum ada guru yang mengikuti kegiatan tersebut. Dari pengembangan diri dapat dinyatakan bahwa kenerja guru pada komponen ini kurang baik.

Pengembangan diri guru wajib dilakukan agar mereka terus bekerja dengan baik. Untuk menunjang dalam melaksanakan pembelajaran, guru senantiasa terus berusaha untuk menambah pengetahuanya sesuai dengan perkembangan jaman. Merencanakan kegiatan pengembangan diri guru misalnya; melalui pelatihan, seminar, workshop, diskusi kelompok kecil, studi banding, tutorial, dan seterusnya. Pengembangan diri sebaiknya dilaksanakan oleh guru dengan baik berdasarkan instruksi dari kepala sekolah atau inisiatif guru sendiri untuk meningkatkan kualitas kinerjanya.

Berdasarkan uraian diatas diperoleh bahwa kinerja guru sertifikasi yang masuk dalam kategori baik meliputi perencanaan pembelajaran, dan penilaian pembelajaran. Komponen kinerja guru yang masuk dalam kategori kurang baik terdapat pada perlaksanaan pembelajaran, dan pengembangan diri.

\section{SIMPULAN DAN SARAN}

\section{Simpulan}

Berdasarkan hasil penelitian dan pembahasan yang telah diuraikan sebelumnya maka disimpulkan bahwa:

1) Kinerja guru sertifikasi di Gugus Mangga pada komponen perencanaan pembelajaran berada pada kriteria baik.

2) Kinerja guru sertifikasi di Gugus Mangga pada komponen pelaksanaan pembelajaran berada pada kriteria kurang baik. 
3) Kinerja guru sertifikasi di Gugus Mangga pada aspek penilaian pembelajaran berada pada kriteria baik.

4) Kinerja guru sertifikasi di Gugus Mangga pada komponen pengembangan diri berada pada kriteria kurang baik.

\section{Saran}

Berdasarkan beberapa temuan di atas maka dapat direkomendasikan hal-hal sebagai berikut:

1) Bagi Guru, untuk menunjang pembelajaran guru hendaknya dapat melengkapi persyaratan pembelajaran dengan baik dengan mengusulkan kepada pihak sekolah yaitu dalam kaitannya buku teks pelajaran. Selain itu guru dalam menyusun RPP sebaiknya memuat teknologi infomasi dan komunikasi. Guru juga perlu mengikuti kegiatan pengembangan diri dalam meningkatkan keprofesiannya. Guru dapat merencanakan kegiatan pengembangan diri guru misalnya; melalui pelatihan, seminar, workshop, diskusi kelompok kecil, studi banding, tutorial, pembinaan dan lain sebagainya.

2) Bagi Kepala Sekolah, pihak sekolah mengusulkan kepada pemerintah daerah meminta bantuan untuk melengkapi buku-buku teks pelajaran agar siswanya dapat belajar dengan baik. Sekolah juga dapat menggunakan dana BOS untuk melengkapi buku teks pelajaran dengan melakukan pembelian secara bertahap.

3) Bagi Dinas Pendidikan, Dinas Pendidikan dapat memberikan bantuan buku teks pelajaran bagi sekolah-sekolah yang belum lengkap buku teks pelajarannya. Selain itu Dinas Pendidikan perlu membuat program pengembangan diri bagi guru dalam rangka pembinaan dan peningkatan kualitas pendidikan.

\section{DAFTAR PUSTAKA}

Arikunto, Suharismi dan Cepi Safrudin. 2008. Evaluasi Program Pendidikan. Jakarta: PT Bumi Aksara

Danim, Sudarwan. 2000. Pengantar Studi Penelitian Kebijakan. Jakarta: Bumi Aksara.

Departemen Pendidikan Nasional. Undang-Undang Republik Indonesia Nomor 14 Tahun 2005 Tentang Guru dan Dosen. Jakarta: Departemen Pendidikan Nasional

Hasibuan, Malayu. 2005. Menejemen sumber daya manusia. Jakarta: Bumi Aksara.

Kemendiknas. 2010. Pedoman kegiatan pengembangan keprofesian berkelanjutan (PKB) dan angka kreditnya. Jakarta: Kemendiknas

Kompas. 2010. Evaluasi Kinerja Guru Bersertifikasi. http://edukasi.kompas.com/read/ 2010/12/05/03121837/Evaluasi.Kinerja.Guru. Bersertifikasi.

Kunandar. 2008. Guru Profesional. Jakarta: PT. Raja Grafindo Persada.

Mangkunegara, Anwar Prabu. 2005. Evaluasi Kinerja SDM. Bandung: PT. Refika Aditama.

Moeheriono. 2012. Indikator Kinerja Utama (IKU): Perencanaan, Aplikasi, dan Pengembangan. Jakarta: Rajawali Pers.

Mulyasa, E. 2003. Kurikulum. Bandung: Remaja Rosdakarya

Mulyasa, E. 2004. Menjadi Kepala Sekolah Profesionalisme, dalam Konteks Menyukseskan $M B S$ dan KBK. Bandung: Remaja Rosdakarya. 
Mulyasa, E. 2007. Standar Kompetensi dan Sertifikasi Guru. Bandung: Remaja Rosdakarya.

Muslich, Masnur. 2007. Sertifikasi Guru Menuju Profesionalisme Pendidik. Jakarta: Bumi Aksara.

Nawawi, Hadari. 2001. Manajemen Sumber Daya Manusia. Jakarta: Ghalia Indonesia.

Peraturan Menteri Pendidikan Nasional Nomor 41 tahun 2007 tentang Standar Proses untuk Satuan Pendidikan Dasar dan Menengah. Jakarta: Depdiknas.

Rivai, Veithzal. 2005. Manajemen Sumber Daya Manusia. Jakarta: Raja Grafindo Persada.

Rusman. 2009. Manejemen Kurikulum. Jakarta: Raja Grafindo Persada.

Sahabuddin. 2014. Sertifikasi guru, kesejahteraan meningkat tetapi kinerja tetap? http://wacana.siap.web.id/2014/09/sertifikasi-guru-kesejahteraan-meningkat-tetapikinerja-tetap.html\#.VGNmQVNtOLN

Sanjaya, Wina. 2005. Pembelajaran dalam implementasi kurikulum berbasis kompetensi. Jakarta: Prenada media

Simanjuntak, Payaman J. 2005. Manajemen dan Evaluasi Kinerja. Jakarta: Salemba Empat.

Sudijono, Anas. 2006. Pengantar Evaluasi Pendidikan. Jakarta: PT. RajaGrafindo Persada

Sudjana, Nana. 2010. Penilaian Proses Belajar Mengajar. Bandung: PT Remaja Rosdakarya

Sunantri, Merawati. 2013. Kinerja dan Kualitas Guru Sertifikasi Dikeluhkan. http://www. suaramerdeka.com/v1/index.php/read/news_solo/2013/11/26/181004/Kinerja-danKualitas-Guru-Sertifikasi-Dikeluhkan

Suratno, M. Rusdi, Hary Soedarta H. 2010. Evaluasi Kinerja Guru Profesional (Studi Kasus Guru Sekolah Dasar di Kota Jambi). Jurnal Penelitian Universitas Jambi Seri Humaniora Volume 12, Nomor 1, Januari - Juni 2010. Hal. 37-44

Uno Hamzah B. dan Nina Lamatenggo. 2012. Teori Kinerja dan Pengukurannya. Jakarta: Bumi Aksara

Widoyoko, Eko Puto. 2014. Evaluasi Program Pembelajaran: Panduan Praktis Bagi Pendidik dan Calon Pendidik. Yogyakarta: Pustaka Pelajar.

Wirawan. 2009. Evaluasi Kinerja Sumber Daya Manusia: Teori Aplikasi dan Penelitian. Jakarta: Salemba Empat.

Yamin, Martinis dan Maisah. 2010. Standarisasi Kinerja Guru. Jakarta: GP Pres.

Yulaelawati, Ella. 2004. Kurikulum dan Pembelajaran. Bandung: Pakar Raya

Yusrizal, Soewarno S, Zarlaida Fitri. 2011. Evaluasi Kinerja Guru Fisika, Biologi dan Kimia SMA yang Sudah Lulus Sertifikasi. Jurnal Penelitian dan Evaluasi Pendidikan. http://journal.uny.ac.id/index.php/jpep/article/download/ 1097/1149. 